\title{
The importance of human resources for the sustainability of business models in the era of industry 4.0
}

\author{
Jana Blštáková1 \\ ${ }^{1}$ Faculty of Business Management, University of Economics in Bratislava, \\ Dolnozemská cesta 1, 85235 Bratislava, Slovakia \\ jana.blstakova@euba.sk
}

\begin{abstract}
One important attribute of the HRM models in the industrial era 4.0 is value changes in the perception of people in the organization with respect to value changes in business. The paper deals with the identification of expression of value changes in human resource management systems and with the definition of a new form of the human resources component in business models. The paper contains partial results of the examination of the position of HR departments and the modern role of personnel specialists and human resource management concepts in the era of industry 4.0.
\end{abstract}

Keywords: Industry 4.0, Human Resources Management, Business Model, Value, Human Capital

\section{Introduction}

The 4.0 industry era represents an environment of fundamental change for human resource management. The theory deals very intensively with the change in the position of human resources management departments in companies and especially in the role of a strategic business partner, emphasizing the importance of corporate culture for the implementation phase of strategic decisions of all kinds. The authors discuss the competencies of personnel specialists and their adaptation to value, systemic and methodological changes in people management. Emphasis is placed on customer orientation and value creation. Strong appeal to segmentation, individual approach, adaptation to customer specifics. Customer-oriented perspective and application of the principles of marketing strategies gets into the concepts of human resource management systems, because the employee becomes an internal customer. Human resource management specialists are expected to know the business, the ability of a process perspective focused on the effectiveness of management systems and entrepreneurship. 


\section{Human resources component in the business model of the company}

Employees and the management of their competencies are determinants of value generation and business performance. The position of human resources and the level of their competencies reflect the values of companies, which in the era of the fourth industrial revolution are moving away from industrialization and capitalization towards innovation and knowledge, as pillars of business competitiveness.

The analysis of the human resources component in the business model in the professional literature consists in identifying the role of human resources in creating the values and performance of business models. In this context, human resources are considered as intellectual or human capital. In general, three perspectives on the perception of human resources as a component of business models are formed, namely as the potential for innovation, strategy implementation or value management [1]. One of the first frameworks that attempted to explain the human resources component in business models to evaluate performance comes from an audit environment. Within this framework, human resources and their competencies have been defined as implicit aspects of the management structure, in the implementation of key processes and in the management of resources [2].

In the Business Model Canvas [3], the definition of value is a central model for understanding the business model, and competencies are an explicit part of the framework as a separate building block. Within the strategic map, the concept of the human factor is understood as either competencies that are considered the basis for value creation or employee satisfaction that affects performance [4]. Other sources in the literature introduce the concept of management and measurement of intellectual capital in connection with the performance of business models, refer to human capital as part of intellectual property and intangible assets, which points to human capital as a pillar of value creation [5]. Intellectual capital is referred to as one of the basic types of knowledge resources that enable an organization to bring value to the customer [6].

The result of the study of business models according to Slávik [7] was an atlas of business models in the era of industry 4.0. He calls post-industrial society knowledge, knowledge, information and networking. Digitization in technological progress has a major impact on the social and economic life in which the service sector predominates, leisure is increased and employees work to meet not only basic living needs but also their cultural needs. Slávik researched business models in the information technology sector, in the film industry and leisure activities, and business models of startups. Innovation, learning, speed, corporate culture, social atmosphere, cooperation and communication are key competences in the information technology sector. Among human resources, creative workers play a dominant role, whose imaginativeness and space for self-realization is crucial, because the entire value-creating process of the company is based on the knowledge, experience and creativity of employees. In the film industry, he considers the result of creative potential, high-quality human resources and the company's image to be a key intellectual strategic resource; in startup structures, these are mainly motivated human resources and commitment. Based on the results of the followup quantitative survey, Slávik states that the most important key sources are considered 
to be employees and know-how, closely followed by the image in the criterion of significance. The high importance of the key resource was also found among managers. The most important skills are communication, speed and innovation.

Based on the results of the research, he states that for a post-industrial society, a typical increase in the role of human resources as an immediate provider of value, or a creator of complex and professionally demanding value, which is usually a highly educated person. The nature of physical work changes from mental to mental work. He describes the business as dematerialized, which uses human resources intensively. The dematerialization of business processes, partnerships and the product itself, accompanied by its sophistication, have significant implications for the content and functionality of the business model in the post-industrial era of business.

Understanding business value creation factors can potentially lead to the identification of key performance indicators. Value creation factors can be seen as links between business objectives and key performance indicators [9]. The author emphasizes that value creation factors are not key result-oriented performance indicators, but rather future-oriented performance measures. Key performance indicators are linked to strategic objectives through the identification of key value factors that can be interpreted as key success factors [9]. The key success factors do not remain static, but change over time, and the cyclical development of business, the business sector and the economy. The result is a change in strategy or business model followed by a redefinition of the capabilities of the process actors involved in the value chain of value added.

Most business model frameworks contain some concept of the impact of the human resource factor that is part of them. However, human resources are used and valued in companies in different ways. One of the ways to identify manifestations of value changes in the world of work of the 4.0 industry era is the perception of people in organizations. We consider the methodology that allows us to perceive business from the perspective of values to be progressive and current. These are the values they create and the valuable / key resources it consumes, as well as the values / revenues that result from the business. In the conditions of the fourth industrial revolution, when we see the growing scarcity of physical resources, growing demands for sustainability of business activities, extreme conditions of competitiveness, growing tendencies to individualize customer approach, which has a global market and a robust information base for perceiving the price-value relationship. analysis of business and entrepreneurial activities as key.

With the growth ambitions of companies in the global environment, the appeal to the ability of entrepreneurship and leadership skills of personnel specialists is stronger. Master knowledge of the nature of business, people management processes and implementation of change can be understood in terms of perfect control of activities, inputs they need and the values they generate, i. e. from a procedural point of view. Participating in the competitiveness of enterprises in the era of industry 4.0 from the architecture of human resource management systems requires a perfect connection to the creation of added value that arises from business [10]. It is equally important to understand its own added value, its sense of business and the effectiveness of the people management processes in which it arises, and to see the position of the customer for whom it is intended. 


\section{$3 \quad$ Research design}

\subsection{Methodology}

Based on theoretical background, many studies state that it is important to examine the management of people in the company in close connection with the values on which the business is based and which are the result of entrepreneurial activity, because the value consistency of the company's activities appears to be a way of managing resources in the 4.0 era. The research question within the implemented research was formulated as follows:

What are the manifestations of value changes in the perception of people in organizations in relation to the values that are preferred in business and that form the core of business models?

The data collection was based on the methodology of an international survey conducted within the CRANET network, data collection was held on in 2017. The subject of the research was the business model of the organization, strategic and operational roles of human resources management, and procedures, processes and methods of human resources management system. The object of the research was companies operating on the Slovak market, while the research sample includes profit oriented companies, as well as non-profit organizations, organizational units of government, or services in the public interest. The questions were organized into four thematic sections (Table 1).

Table 1. Questionnaire components.

\begin{tabular}{ll}
\hline \multicolumn{1}{c}{ Section } & \multicolumn{1}{c}{ Subject of the research } \\
\hline $\begin{array}{l}\text { Characteristics of human } \\
\text { partment }\end{array}$ & $\begin{array}{l}\text { characteristics of the organization in terms of number } \\
\text { and structure of employees, forms of ownership, busi- } \\
\text { ness sectors, market characteristics and market posi- } \\
\text { tion of the organization } \\
\text { specification of the position of the human resources } \\
\text { management department, representation of the depart- } \\
\text { ment in the top management of the organization, for- } \\
\text { mulation of strategic documents } \\
\text { level of conception / implementation of people man- } \\
\text { agement policies, } \\
\text { specification of the strategic and operational role of } \\
\text { the personnel department } \\
\text { basic performance indicators of the personnel depart- } \\
\text { ment (fluctuation, incapacity for work, tendency to de- } \\
\text { velop a satisfaction survey) } \\
\text { key values of organizational culture } \\
\text { values that result from the business activities of the } \\
\text { organization } \\
\text { key resources } \\
\text { key activities } \\
\text { forms of customer relations, and forms of sales } \\
\text { cost structure and revenue structure }\end{array}$ \\
\hline Business model
\end{tabular}




\begin{tabular}{ll}
\hline $\begin{array}{l}\text { Employee potential } \\
\text { forming }\end{array}$ & $\begin{array}{l}\text { methods and procedures of the process of recruitment } \\
\text { and selection of employees, elements of digitization } \\
\text { flexibility of the workplace, and work regimes } \\
\text { workplace diversity management programs }\end{array}$ \\
\hline $\begin{array}{l}\text { Employee potential de- } \\
\text { velopment }\end{array}$ & $\begin{array}{l}\text { the concept of employee evaluation and training } \\
\text { performance management methods and procedures } \\
\text { succession plans and career management } \\
\text { remuneration, financial and non-financial instru- } \\
\text { ments, and employee benefits and services } \\
\text { tools for internal communication and employee rela- } \\
\text { tionship management }\end{array}$ \\
\end{tabular}

The synthesis and interpretation of the findings from the questionnaire survey focuses on the value perception of people in companies in the environment of digital tendencies in the processes, procedures and tools of human resource management. We define the model of the human resources management system in the era of industry 4.0 according to the value changes of the perception of people in the organization with respect to the value changes of business.

\subsection{Research sample}

The research sample of the survey based on the concept of the international survey CRANET, carried out in 2017, contains answers from 181 respondents. Due to the fact that the survey has a certain continuity and there is awareness in the community of HR leaders in Slovakia, and was also carried out by a combination of face-to-face meetings and electronic data collection tools, a high return rate $(98.15 \%)$ was achieved.

The characteristics of the composition of the research sample in terms of size according to the number of employees are shown in the table. Micro enterprises and family enterprises $(32.7 \%)$ make up a third of the research sample and large enterprises are also represented (7.2\%). For the purpose of examining research issues in the habilitation thesis, we will further analyze organizations with more than 50 employees.

Most of the organizations in the research sample operate in the private sector $(86.4 \%)$, other organizations operate in the public sector or in a mixed-type organization. More than a third (37.2\%) of organizations have established their activities mainly with a global reach, the others operate nationally $(31.4 \%)$ or regional $(25 \%)$. We record regional scope, especially for small companies, which will not be the subject of further research.

In the research sample, the ratio of organizations operating in production, manufacturing and trade $(54.17 \%)$ and services $(43.3 \%)$ is relatively balanced. Based on participation in the international survey and data from continuous research from previous periods, we state a tendency for a higher representation of companies operating in the service sectors. 


\section{$4 \quad$ Research results}

We performed the analysis of the business model by applying the CANVAS model. The purpose of examining the human resource component in the business model was to find out the values that organizations consider to be the core of their business and the organization as the reason for their activities. Furthermore, the intention was to analyse the key resources that the company uses to generate added value. The subject of the analysis is the relationship between the value of the business, and the resources (especially the human resources component) that organizations consider key to their business.

Based on the results obtained, we state that the added value of products / services that organizations most often mentioned is high quality (68\%), customer care $(52.5 \%)$ and innovation (35.9\%) (see Figure 1). the low price, design, or convenience of purchasing an organization occurred less frequently in the responses. Among the key business sources of the organization, human resources $(56.40 \%)$, intellectual capital $(50.3 \%)$ and tangible resources $(41.4 \%)$ were listed among the three priorities (see Figure 2). It follows that the resources that organizations consider to be key to creating added value are directly linked to people.

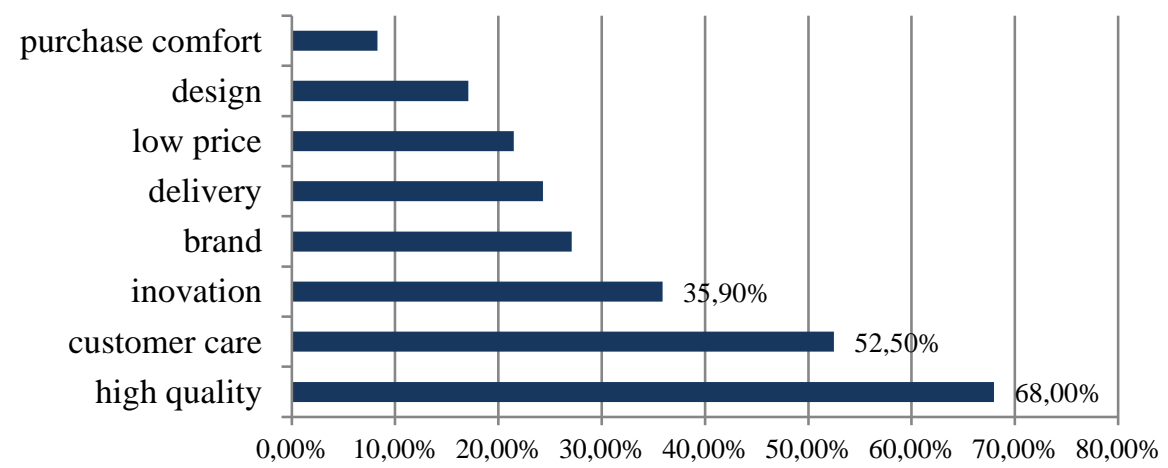

Fig. 1. Value as the result of business

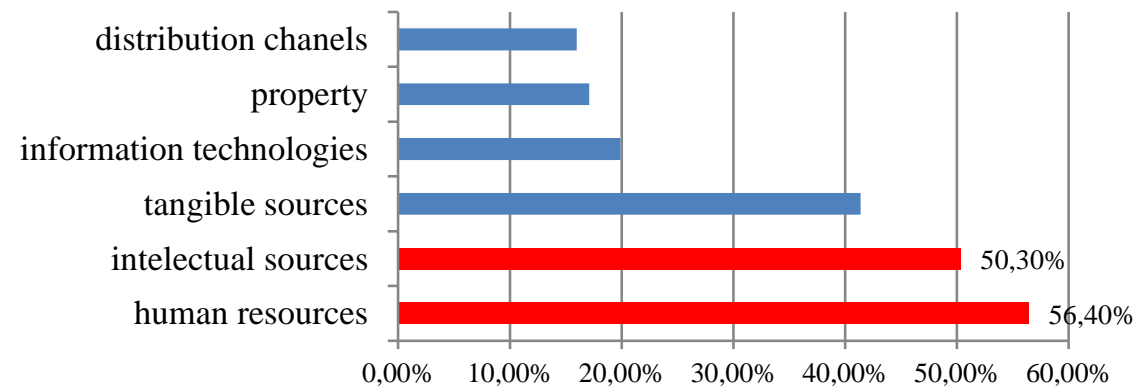

Fig. 2. Key sources of business 
The human resources component was analyzed in relation to the values that companies identified as key to their business. It can be stated that companies that mentioned product and service innovation as the value of their business activity most often saw human resources $(64.62 \%)$ and intellectual resources $(63.08 \%)$ as key sources (see Figure 3). Less important, but not negligible, are material resources for their business (47.69\%), real estate was identified as a key resource very rarely $(9.23 \%)$. The results also showed that companies that cited design as a value source are the results of intellectual activity, so they perceive people more as intellectual capital $(61.29 \%)$ than human resources $(45.61 \%)$. We record a similar situation in companies where the value is a stylish brand, the difference is significantly smaller. Information technology $(46.67 \%)$ is key in companies where the value is the convenience of shopping or innovation (33.85\%). Real estate $(33.3 \%)$ and tangible resources $(51.28 \%)$ were most often identified as key resources by companies that focus on low prices as the value of their business

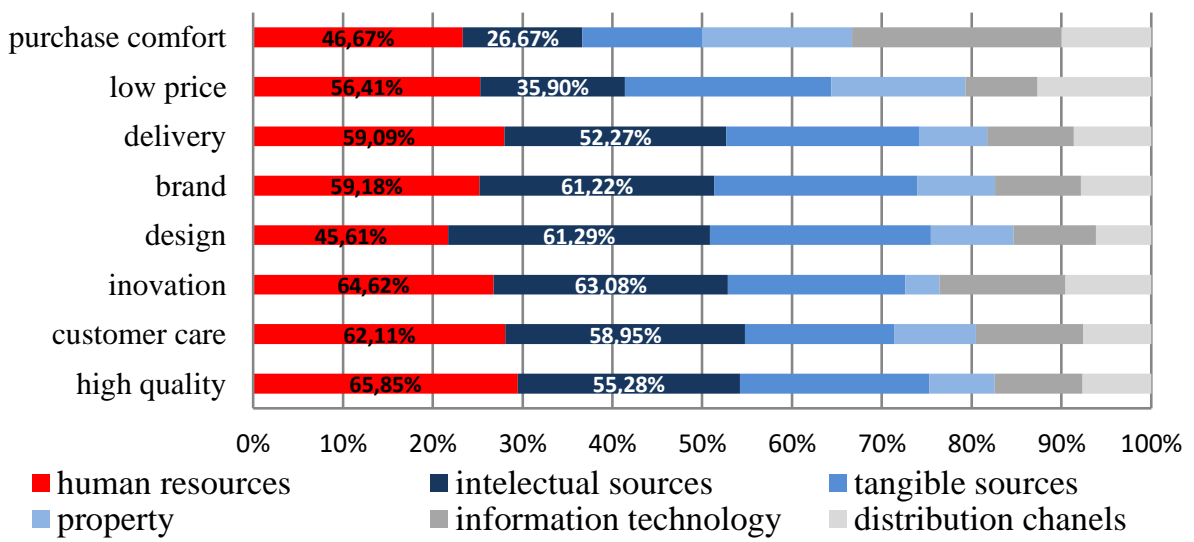

Fig. 3. Key value related to key business sources

Based on the analysis of the human resources component in the business model, it is clear that companies, regardless of the value that results from their business, consider human resources and the result of their intellectual activity as key business resources. The importance of people to business changes in relation to the value that business generates. Within the examined set of companies, the obtained results confirmed the importance of the human factor as a determinant of the use of other production factors of companies in the conditions of the fourth industrial revolution, which results in a stronger focus on intellectual outputs of human activity. By analyzing other contexts of other thematic sections from the questionnaire survey, we found out how value changes in business are reflected in human resource management systems, with a focus on the formation and development of work potential.

\section{Discussion}

We consider among the manifestations of fundamental value changes a change in the role of man in production systems, the consequence of which is a change in the required 
competence of employees. Businesses pay special attention to recruiting and selecting employees. They pay attention to the competitiveness of work potential formation systems, within which they implement concepts focused on the attractiveness of the employer and the retention of employees. Unfavorable demographic developments in EU countries and the phenomenon of overseas brain drain put the position of employers on the labor market at a greater disadvantage. On the other hand, the demands on the knowledge, skills and competences of the new generation of employees are a challenge for the labor market as well as current education systems [11]. Modern employers expect technological (business knowledge, technological skills, process orientation, programming), methodological (analytical skills, entrepreneurship, creativity, efficiency orientation), social (communication skills, ability to work in a team, ability to lead) and personal (flexibility, tolerance , motivation) competence..

The consequence is therefore the situation on the labor market where the demand for labor remains unsaturated due to inadequate supply, both in terms of quantity and structure. This difference grows stronger and takes the form of opening scissors. According to personnel specialists, the situation in Slovakia is critical and will lead to value changes. Ján Odzgan, Strategic Advisor to the CEO for Change Management at Bank, states that there is such a shortage of really valuable people in the labor market that we begin to perceive the reversal of roles in selection interviews. It is possible that there will be a time when candidates will not come to the selection interview, but representatives of organizations will visit a potential employee and compete with each other to offer him more attractive conditions [12]. Requiring and developing skills such as entrepreneurship, creativity, analytical thinking, with the intention of increasing the degree of autonomy, responsibility, and readiness to perform tasks of a strategic nature, leads to a reassessment of the object of management [13]. The object of management becomes the competence of people and their potential, which is carried by the people themselves. The employee gets into the role of a customer whose potential is of interest.

To the question of what are the manifestations of value changes in the perception of people in organizations in relation to the values that are preferred in business and which form the core of business models, we answer by examining the concepts of formation and development of work potential. We note that HR specialists shape the corporate culture and declare the values that are the pillars of the company's strategy to support the implementation phase towards current employees, while creating a clear picture of expected organizational behavior, as well as opportunities for candidate aspirations and career management programs.

Human resource management departments take on the role of business partner, partner in creating added value of the organization, and department leaders take a formal position in the top management of organizations, because the presence of people management experts in the phase of creating corporate strategy is desirable. Personnel specialists in Slovakia tend to focus more on the implementation of processes than on their outcome. This tendency needs to be changed by focusing on the results of their work, the effectiveness and efficiency with which they have been achieved and their meaning (significance) for the value-creating activities of the organization. To meet this requirement, the effectiveness of HRM processes should be measurable and their impact on other processes of the organization demonstrable [14]. However, the HRM system can 
only justify the significance of its activities and the degree of their impact on the overall performance of the organization through measurable results, which is necessary for the acquisition of the character of a strategic partner.

In 2015, the topics of professional conferences of the community of personnel specialists in Slovakia focused on the formation of work potential, such as the concept of employer branding, defining the expected value of the employee (Employee value proposition, so-called EVP), programs for obtaining references (Referral program), Employee engagement, employee diversity new generation of employees (Millennials), employee aging (successor programs). Furthermore, it was measuring the performance of human resources departments, the choice of performance indicators of the leader of the human resources department, the human resources management system in times of change and the transformation of corporate culture. The subject of discussions is the digital age in people management, the tools and opportunities it brings and the competencies it requires. In 2017, the central theme is the era of the employee, the employee in the role of ambassador and a positive employee experience. Businesses need to be attractive to employees / candidates, they want to manage emotions. Emotions are variable, depending on the customer / employee experience. At present, exceptionality is becoming a source of attraction. Attractive people management systems persistently analyze the values inherent in employees / candidates, the experience they have come to gain, the experience they expect. The feeling of excellence is evoked by the interest and focus on the individual specifics and expectations of the employee / customer.

\section{Conclusion}

Industrial development is an integrated process between man and machine through its own complexity. We are witnessing a time when humanity owns more than ever before. It is the result of man's creative activity, the result of which is technological progress. Growth as the only acceptable result drives companies to more and more sophisticated concepts of competitiveness [15] (Stacho et al., 2020). Technological progress is shrinking the physical world and shaping a virtual world whose potential appears without limits. The world of work during the Fourth Industrial Revolution is the subject of scientific research, professional discussions, but also a reason to express concerns about changes in the nature of work, the demand for work and social insecurity.

The genesis of the development of human research in the organization began with the separation of man from the production line, continued with the focus on his personality and needs, further developed by perceiving his aspirations, later values and today is an important work experience.

Current developments in the world of work are referred to as the "Employee age", where people management specialists formulate customer-oriented concepts focused on the positive experience of the internal customer (employee), while focusing on financial performance, strategy and market share (customer). Businesses need to be attractive to employees, that is, they want to manage their emotions. In the global world of overexposed information, the value of experience is experiencing a renaissance, and exceptionality is becoming a source of attraction. Systemic, technological, but 
especially value changes, which are the result of progress, define modern concepts of people management, roles and competencies of their bearers. In business models, the human resources component is consistently the most important determinant of the result of the interaction of other components and the resulting added value.

\section{Acknowledgement}

Supported by the Scientific Grant Agency of the Ministry of Education of Slovak Republic and the Slovak Academy of Sciences funded by VEGA No. 1/0412/19 Systems of Human Resources Management in the 4.0 Industry

\section{References}

1. Fielt, E.: Understanding Business Models. Business Service Management Journal. Vol. 3. 2011.

2. Nielsen, C., Lund, M.: Business Models: Networking, Innovating and Globalizing, Ventus Publishing, Copenhagen.2012: www.Bookboon.com., last accessed 2017/10/02

3. Osterwalder, A.,Pigneur, Y.: Business Model Generation. Handbook for Visionaries, Game Changers, and Challengers. Hoboken: Wiley. 2010

4. Kaplan, R.S.,Norton, D. P.: Efektívní systém řízení strategie. Nový nástroj zvyšování výkonnosti a vytváření konkurenční výhody. Management Press, Praha 2010.

5. Sveiby, K.E.: The New Organizational Wealth: Managing and Measuring Knowledge-based Assets. Berrett-Koehler, San Francisco, 1997

6. The New Guideline Copenhagen, Danish Ministry of Science, Technology and Innovation, available at: www.vtu.dk/icaccounts, last accessed 2017/12/02

7. Slávik, S.: Podnikatel'ské modely, EKONÓM, Bratislava, 2014.

8. Guthrie, J., Dumay, J., Ricceri, F., Nielsen, CH.: New Directions in Business: Performance Reporting, Communication and Assurance. The Institute of Chartered Accountants in Australia, Routledge, Sydney, 2017

9. Lorincova, S., Hitka, M., Starchon, P.: Strategic Instrument for Sustainability of Human Resource Management in Small and Medium-Sized Enterprises Using Management Data. Sustainability, Vol.10, Issue 10, 2018

10. Papula J., Kohnová L., Papulová Z.: Industry 4.0: Preparation of Slovak Companies, the Comparative Study. Smart Technology Trends in Industrial and Business Management. EAI/Springer Innovations in Communication and Computing. Springer, (2019)

11. Vetrakova, M., Hitka, M., Potkany, M.: Corporate Sustainability in the Process of Employee Recruitment through Social Networks in Conditions of Slovak Small and Medium Enterprises. Sustainability, Vol. 10, Issue 5, 2018

12. Odzgan, J.: Change before you have to. HRlive, Vol. 2.Issue IV, 2017

13. Ližbetinová, L., Hitka, M.: Selection of Most Suitable Candidates for the Talent Pool in a Furniture Manufacturing Company. Drvna Industrija. 2017

14. Kucharčíková, A., Mičiak, M.: Human capital management in transport enterprises with the acceptance of sustainable development in the Slovak Republic. Sustainability, Vol. 10, issue 7, 2018

Stacho, Z., Stachova, K., Caganova, D: Participation of all Employee Categories in Innovation Processes in Slovak Organisations. Mobile Networks and Applications, 2020 